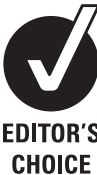

EDITOR'

CHOICE

- An additional data is published online only. To view this file please visit the journal online (http://oem.bmj.com)

${ }^{1}$ Centre for Public Health Forecasting, National Institute for Public Health and the Environment, Bilthoven, The Netherlands

${ }^{2}$ Centre for Prevention and Health Services Research, National Institute for Public Health and the Environment, Bilthoven, The Netherlands

\section{Correspondence to} Heleen H Hamberg-van Reenen, Centre for Public Health Forecasting, National Institute for Public Health and the Environment, PO Box 1, Bilthoven 3720 BA

The Netherlands; heleen.hamberg@rivm.nl

Accepted 1 July 2012 Published Online First 3 August 2012

\title{
Worksite mental health interventions: a systematic review of economic evaluations
}

\author{
Heleen H Hamberg-van Reenen, ${ }^{1}$ Karin I Proper, ${ }^{2}$ Matthijs van den Berg ${ }^{1}$
}

\begin{abstract}
Objective To give an overview of the evidence on the cost-effectiveness (CE) and financial return of worksite mental health interventions.

Methods A systematic search was conducted in relevant databases. Included economic evaluations were classified into two groups based on type of intervention: (1) aimed at prevention or treatment of mental health problems among workers or (2) aimed at return to work (RTW) for workers sick-listed from mental health problems. The quality of the included economic evaluations was assessed using the Consensus Health Economic Criteria list (CHEC-list).
\end{abstract}

Results Ten economic evaluations were included in this systematic review. All four economic evaluations on the prevention or treatment of mental health problems found a positive cost-benefit ratio, although three of these studies had low to moderate methodological quality. In five out of six economic evaluation studies on RTW interventions, no favourable CE or cost-benefit balance was found. One study of moderate methodological quality reported on a positive CE balance.

Conclusions Due to a limited number of economic evaluations on worksite mental health interventions of which a majority was lacking methodological quality or lacking evidence, only a tentative conclusion can be drawn from the results of this systematic review. Worksite interventions to prevent or treat mental health problems might be cost-effective, while those RTW interventions that included a full economic evaluation aimed at depressed employees do not seem to be costbeneficial. More high-quality economic evaluation studies of effective worksite mental health interventions are needed to get more insight into the economic impact of worksite mental health interventions.

\section{INTRODUCTION}

The prevalence of mental health problems is high ${ }^{1}$ and rising. ${ }^{2}$ Worldwide, 450 million people suffer from a mental health problem. ${ }^{3}$ In The Netherlands, the lifetime prevalence of mental health problems is over $40 \%{ }^{4}$ Among the working population in developed countries, the 1-year prevalence rates of mental health problems range from $10 \%$ to $18 \% .^{5}{ }^{6}$ Mental health problems can affect the individual's ability to work leading to absence due to sickness, and on the longer-term work disability. In 2008, mental health problems were one of the first three leading causes of work disability, ${ }^{7}$ but it has been predicted that by 2020 , mental health problems, in particular depression, will rate as the leading cause of work disability. ${ }^{8}$ Figures from The Netherlands have shown that $19 \%$ of all absence due to sickness was caused by mental health problems. ${ }^{9}$ In $2005,38 \%$ of disability benefits in The Netherlands was paid because of mental health problems. ${ }^{10}$ Due to medical consumption and lost productivity, mental health problems are associated with high costs. ${ }^{11} 12$ The costs of mental health problems in developed countries have been estimated at between 3\% and $4 \%$ of the Gross National Product. ${ }^{3}$

Employers may benefit from interventions aimed at promoting employees' mental health. There are several types of mental health interventions for (sick-listed) workers, varying from group interventions, to counselling by a general practitioner (GP), mental health coach or occupational physician, to medication, to cognitive behavioural therapy among others. Mental health interventions can either target the working population not (or short-term) sick-listed due to mental health problems (ie, prevention and treatment), or the working population at long-term absence due to mental health problems (ie, return-to-work (RTW) interventions). More in detail, primary preventive interventions target the entire workforce in order to increase mental health and to prevent mental health problems; secondary preventive interventions target high-risk workers, and aim to reduce mental health problems and to prevent sick leave. Treatment interventions target the working population with mental health problems either at shortterm absence or not. RTW interventions, finally, are focused on improving RTW of workers who are sick-listed due to mental health problems.

Several interventions have effectively been used in the prevention or treatment of mental health problems, for instance, medication or cognitive behavioural therapy. ${ }^{13}$ However, when focusing on worksite mental health interventions, mixed results on mental health and work productivity have been shown in several reviews. ${ }^{14-20}$ To illustrate, Ruotsalainen et al ${ }^{14}$ found small but significant effects of person-directed interventions on the reduction of stress, burnout and anxiety. However, the evidence was limited due to lack of highquality trials. In addition, Richardson and Rothstein $^{15}$ found a medium to large effect of stress management interventions on work productivity. As to RTW interventions, Van Oostrom et $a l^{16}$ in their systematic review could not draw a conclusion on the effectiveness of worksite mental health interventions because of lack of randomised controlled trials (RCTs)

Besides the effectiveness of worksite interventions aimed at promoting mental health, it is of interest for employers whether investment in the programme is cost-effective (ie, the effects on mental health or quality of life (OALYs; quality 
adjusted life-years) present good value for the money invested) or cost beneficial (ie, the financial benefits, eg, due to decreased absence rates, exceed the investment costs, in other words, the 'return on investment' (ROI) is favourable). There are several reviews of economic evaluations on mental health interventions in the general population, ${ }^{20-22}$ but no firm conclusions could be drawn due to limited high-quality economic evaluations. As far as we know, there is no systematic overview of economic evaluations on worksite mental health interventions. Therefore, the objective of this systematic review is to give an overview of the evidence on the cost-effectiveness (CE) and financial return of interventions aimed at preventing or treating mental health problems, or to improve RTW of workers sicklisted from mental health problems.

\section{METHODS \\ Search}

We searched for economic evaluations of worksite mental health interventions in different databases, that is, Medline, Scopus, NHS-EED/HTA and PsychInfo. A search strategy was drawn up according to 'PICO', that is, defining search terms on Population, Intervention, Comparator/Control intervention and Outcome. The search terms were related to the population (eg, workers, working population, occupational), different types of intervention (eg, prevention, treatment, RTW) and outcome (eg, mental health, stress, CE, cost benefits, ROI, economic evaluation). No criteria were set for the content and format of the comparator or control intervention. The search was supported by a library specialist. The complete Medline search string can be found in the Appendix. The search strings for the other databases were based on this strategy.

We selected studies in English from 1 January 2000 to 14 June 2011. Inclusion criteria were: a working population (either sick-listed or not), an intervention on mental health problems (either prevention, treatment or an RTW intervention), and representing a full economic evaluation, with an outcome on CE (ie, comparing costs and effects in mental health), cost utility (ie, comparing costs and effects in quality-adjusted lifeyears (OALYs)), or cost benefits (ie, comparing costs and financial benefits, which are net benefits, or ROI). Articles which reported only on outcome measures or on costs (non-economic evaluations or cost studies) were excluded. Furthermore, studies on work resumption for psychiatric hospitalised patients were excluded, as well as economic evaluations on medication as solely interventional for mental health problems. Finally, economic evaluations including persons on sick leave with subgroup analyses regarding mental health problems were excluded. Only economic evaluations focusing on mental health interventions as primary target were included.

Included economic evaluations on mental health interventions were classified into two groups based on the target population of workers whether or not on absence due to sickness: (1) prevention or treatment for non-sick-listed, or short-term sick-listed workers, with or without mental health problems; (2) RTW interventions for (long-term) workers sick-listed due to mental health problems.

The selection of the studies was done by three reviewers $(\mathrm{HH}, \mathrm{KP}, \mathrm{MvdB})$, and was first based on title and abstract. Moreover, the reference lists of the included economic evaluations, as well as related reviews were checked, and authors of related articles were contacted to ask for information on the performance of an economic evaluation. In case of uncertainty about eligibility, the publication was discussed in a joint meeting and, if necessary, the full text was retrieved and read for eligibility.

\section{Data extraction}

From the selected economic evaluation studies, data were extracted using a predefined form on general study characteristics, characteristics of the economic evaluation and study outcome. General characteristics included authors, publication date, country, study population, intervention and control condition.

Characteristics of the economic evaluations included the design of the study (ie, economic evaluation alongside an RCT or a modelling study), the perspective from which the cost calculations were done (ie, the society including 'all' costs, or the employer), the intervention period and 'time horizon' (follow-up period), the measurement of effectiveness or financial benefits and measurement of costs, and finally, if sensitivity analyses or uncertainty analyses are carried out (ie, analyses estimating the robustness of the outcome, or indicating the variables that are the outcomes most sensitive).

Study outcome included effectiveness or financial benefits, costs and combined costs and effects (ie, incremental CE ratio, incremental cost-utility ratio (ICUR), cost difference (net costs or benefits), cost-benefit ratio, or ROI: percentage, and sensitivity analyses or uncertainty analyses). See Drummond et a $\mathbf{l}^{23}$ for further information on economic evaluations.

Data extraction was carried out by two sets of authors independently; half the studies by $\mathrm{HH}$ and $\mathrm{KP}$, and the remaining by $\mathrm{HH}$ and $\mathrm{MvdB}$. Discrepancies were resolved in a consensus meeting.

\section{Assessment of methodological quality}

The quality of the included economic evaluations was assessed using the Consensus Health Economic Criteria list (CHEC-list) (see table 1). ${ }^{24}$ This checklist was developed based on a consensus procedure between international experts. The checklist contains 19 questions on different aspects of economic evaluations, for example, study design, time horizon, perspective, type of costs and effectiveness measures that are included, the way these are measured and valued, incremental analysis of costs and outcomes, discounting, sensitivity analyses, authors' conclusions and generalisability of study results. Each question can be answered 'yes' or 'no'. If the answer is 'yes', this means that the study either adequately performed the item of concern or reported the item in an appropriate way. The CHEC list was filled in by two sets of authors independently, half by $\mathrm{HH}$ and $\mathrm{KP}$, and half by $\mathrm{HH}$ and MvdB. Discrepancies were resolved in a consensus meeting.

In this review, cut-off points to categorise studies into high, moderate and low quality were chosen, indicating low, moderate and high risk of bias, respectively. Studies that fulfilled $>75 \%$ of the items were classified as high quality, fulfilment between $>50 \%$ and $\leq 75 \%$ was classified as moderate quality, and $\leq 50 \%$ fulfilment was classified as low quality. ${ }^{34} 35$

\section{RESULTS}

\section{Study selection}

The database search resulted in 3886 hits of which title and abstract were screened (see figure 1); 3868 articles were excluded for several reasons, such as: no working population, no intervention on mental health problems, or no full economic evaluation. The full texts of the remaining 18 articles were studied, of which 10 articles were included in this review. Checking reference lists of the included studies and related 
Table 1 Quality scores for criteria of the CHEC list; percentage of fulfilment included economic evaluations focused on prevention or treatment and on return to work (RTW), respectively

\begin{tabular}{|c|c|c|c|c|c|c|c|c|c|c|c|c|c|}
\hline & \multicolumn{5}{|c|}{ Prevention/treatment } & \multicolumn{8}{|c|}{ Return to work } \\
\hline & $\begin{array}{l}\text { Lo Sasso } \\
\text { et } \mathrm{a}^{25}\end{array}$ & $\begin{array}{l}\text { Bittman } \\
\text { et } a l^{26}\end{array}$ & $\begin{array}{l}\text { Wang } \\
\text { et } a l^{6}\end{array}$ & $\begin{array}{l}\text { Vogt } \\
\text { et }\left.a\right|^{27}\end{array}$ & $\begin{array}{l}\text { Subtotal } \\
\text { (\% ful-filment) }\end{array}$ & $\begin{array}{l}\text { Van } \\
\text { Oostrom } \\
\text { et } a^{28}\end{array}$ & $\begin{array}{l}\text { Brouwers } \\
\text { et } \mathrm{al}^{29}\end{array}$ & $\begin{array}{l}\text { Leon } \\
\text { et }\left.a\right|^{30}\end{array}$ & $\begin{array}{l}\text { Rebergen } \\
\text { et } a^{31}\end{array}$ & $\begin{array}{l}\text { Schene } \\
\text { et } a l^{32}\end{array}$ & $\begin{array}{l}\text { Uegaki } \\
\text { et } a^{33}\end{array}$ & $\begin{array}{l}\text { Subtotal } \\
\text { (\% fulfilment) }\end{array}$ & $\begin{array}{l}\text { Total } \\
\text { (\% fulfilment) }\end{array}$ \\
\hline 1. Is the study population clearly described? & 1 & 0 & 0 & 0 & 25 & 1 & 0 & 1 & 1 & 1 & 1 & 83 & 60 \\
\hline $\begin{array}{l}\text { 2. Are competing alternatives clearly } \\
\text { described? }\end{array}$ & 1 & 1 & 0 & 0 & 50 & 1 & 1 & 0 & 1 & 1 & 0 & 67 & 60 \\
\hline $\begin{array}{l}\text { 3. Is a well-defined research question posed in } \\
\text { answerable form? }\end{array}$ & 0 & 0 & 1 & 0 & 25 & 1 & 1 & 1 & 1 & 1 & 1 & 100 & 70 \\
\hline $\begin{array}{l}\text { 4. Is the economic study design appropriate to } \\
\text { the stated objective? }\end{array}$ & 1 & 1 & 1 & 0 & 75 & 1 & 1 & 0 & 1 & 1 & 1 & 83 & 80 \\
\hline $\begin{array}{l}\text { 5. Is the chosen time horizon appropriate in } \\
\text { order to include relevant costs and } \\
\text { consequences? }\end{array}$ & 0 & 1 & 1 & 1 & 75 & 1 & 1 & 1 & 1 & 1 & 1 & 100 & 90 \\
\hline $\begin{array}{l}\text { 6. Is the actual perspective chosen } \\
\text { appropriate? }\end{array}$ & 1 & 0 & 1 & 0 & 50 & 1 & 0 & 0 & 1 & 0 & 1 & 50 & 50 \\
\hline $\begin{array}{l}\text { 7. Are all important and relevant costs for } \\
\text { each alternative identified? }\end{array}$ & 1 & 0 & 1 & 0 & 50 & 1 & 1 & 1 & 1 & 1 & 1 & 100 & 80 \\
\hline $\begin{array}{l}\text { 8. Are all costs measured appropriately in } \\
\text { physical units? }\end{array}$ & 0 & 0 & 0 & 0 & 0 & 1 & 1 & 0 & 1 & 0 & 1 & 67 & 40 \\
\hline 9. Are costs valued appropriately? & 1 & 0 & 0 & 0 & 25 & 1 & 0 & 0 & 1 & 0 & 1 & 50 & 40 \\
\hline $\begin{array}{l}\text { 10. Are all important and relevant outcomes } \\
\text { for each alternative identified? }\end{array}$ & 1 & 0 & 1 & 1 & 75 & 1 & 1 & 1 & 1 & 1 & 1 & 100 & 90 \\
\hline 11. Are all outcomes measured appropriately? & 1 & 1 & 0 & 0 & 50 & 1 & 0 & 0 & 1 & 0 & 1 & 50 & 50 \\
\hline 12. Are outcomes valued appropriately? & 1 & 0 & 1 & 0 & 50 & 1 & 1 & 0 & 1 & 0 & 1 & 67 & 60 \\
\hline $\begin{array}{l}\text { 13. Is an incremental analysis of costs and } \\
\text { outcomes of alternatives performed? }\end{array}$ & 1 & 0 & 1 & 0 & 50 & 1 & 1 & 0 & 1 & 1 & 1 & 83 & 70 \\
\hline $\begin{array}{l}\text { 14. Are all future costs and outcomes } \\
\text { discounted appropriately? }\end{array}$ & 1 & 0 & 1 & 0 & 50 & 1 & 0 & 1 & 1 & 0 & 1 & 67 & 60 \\
\hline $\begin{array}{l}\text { 15. Are all important variables, whose values } \\
\text { are uncertain, appropriately subjected to } \\
\text { sensitivity analysis? }\end{array}$ & 1 & 0 & 1 & 0 & 50 & 1 & 1 & 1 & 1 & 0 & 1 & 83 & 70 \\
\hline $\begin{array}{l}\text { 16. Do the conclusions follow from the data } \\
\text { reported? }\end{array}$ & 1 & 0 & 1 & 0 & 50 & 1 & 1 & 0 & 1 & 0 & 1 & 67 & 60 \\
\hline $\begin{array}{l}\text { 17. Does the study discuss the generalisability } \\
\text { of the results to other settings and patient/ } \\
\text { client groups? }\end{array}$ & 1 & 0 & 0 & 0 & 25 & 1 & 0 & 0 & 1 & 1 & 0 & 50 & 40 \\
\hline $\begin{array}{l}\text { 18. Does the article indicate that there is no } \\
\text { potential conflict of interest of study } \\
\text { researcher(s) and funder(s)? }\end{array}$ & 1 & 1 & 0 & 1 & 75 & 1 & 1 & 0 & 1 & 1 & 1 & 83 & 80 \\
\hline $\begin{array}{l}\text { 19. Are ethical and distributional issues } \\
\text { discussed appropriately? }\end{array}$ & 0 & 0 & 0 & 0 & 0 & 0 & 0 & 0 & 0 & 0 & 0 & 0 & 0 \\
\hline Total (\% fulfilment) & 79 & 26 & 58 & 16 & 45 & 95 & 63 & 37 & 95 & 53 & 84 & 71 & 61 \\
\hline
\end{tabular}

0, no; 1, yes; CHEC, Consensus Health Economic Criteria. 
reviews (which were found in this search based on title and abstract), as well as inquiring with authors of related articles did not yield additional articles. Finally, four economic evaluations on the prevention or treatment of mental health problems were included, ${ }^{6}{ }^{25-27}$ and six economic evaluations of RTW interventions for workers sick-listed due to mental health problems. $^{28-33}$

\section{General study characteristics}

Table 2describes the general characteristics of the studies that evaluated the economic impact of interventions aimed at preventing or reducing mental health problems, or aimed at RTW for workers sick-listed due to mental health problems.

\section{Prevention and treatment}

Of the four economic evaluations that focused on the prevention or treatment of mental health problems, interventions consisted of enhanced care, ${ }^{625}$ a recreational music-making intervention, ${ }^{26}$ and a Critical Incident Stress Management (CISM) Programme. ${ }^{27}$ One of these interventions was applied to healthy long-term care workers (ie, without mental health problems), ${ }^{26}$ the other interventions were among mixed groups of blue collar and white collar workers with depression, ${ }^{6}{ }^{25}$ or having experienced a critical incident at air traffic controller work. ${ }^{27}$ They all had a cost-benefit design, and one study additionally performed a cost-utility analysis. ${ }^{6}$ Two cost-benefit analyses from the USA reported on net benefit, or ROI, from the employers' perspective. ${ }^{65}$ In these studies, the employers' perspective was defined as follows: costs included intervention costs, and benefits were related to increased work productivity. The additional CE analysis was reported from the societal perspective ${ }^{6}$ in which the intervention and healthcare costs were compared with the effect on QALY. From the other two cost-benefit analyses from Denmark ${ }^{27}$ and the USA, ${ }^{26}$ no information was given on study perspective. Two of four economic evaluations on prevention or treatment carried out a sensitivity analysis, ${ }^{6} 25$

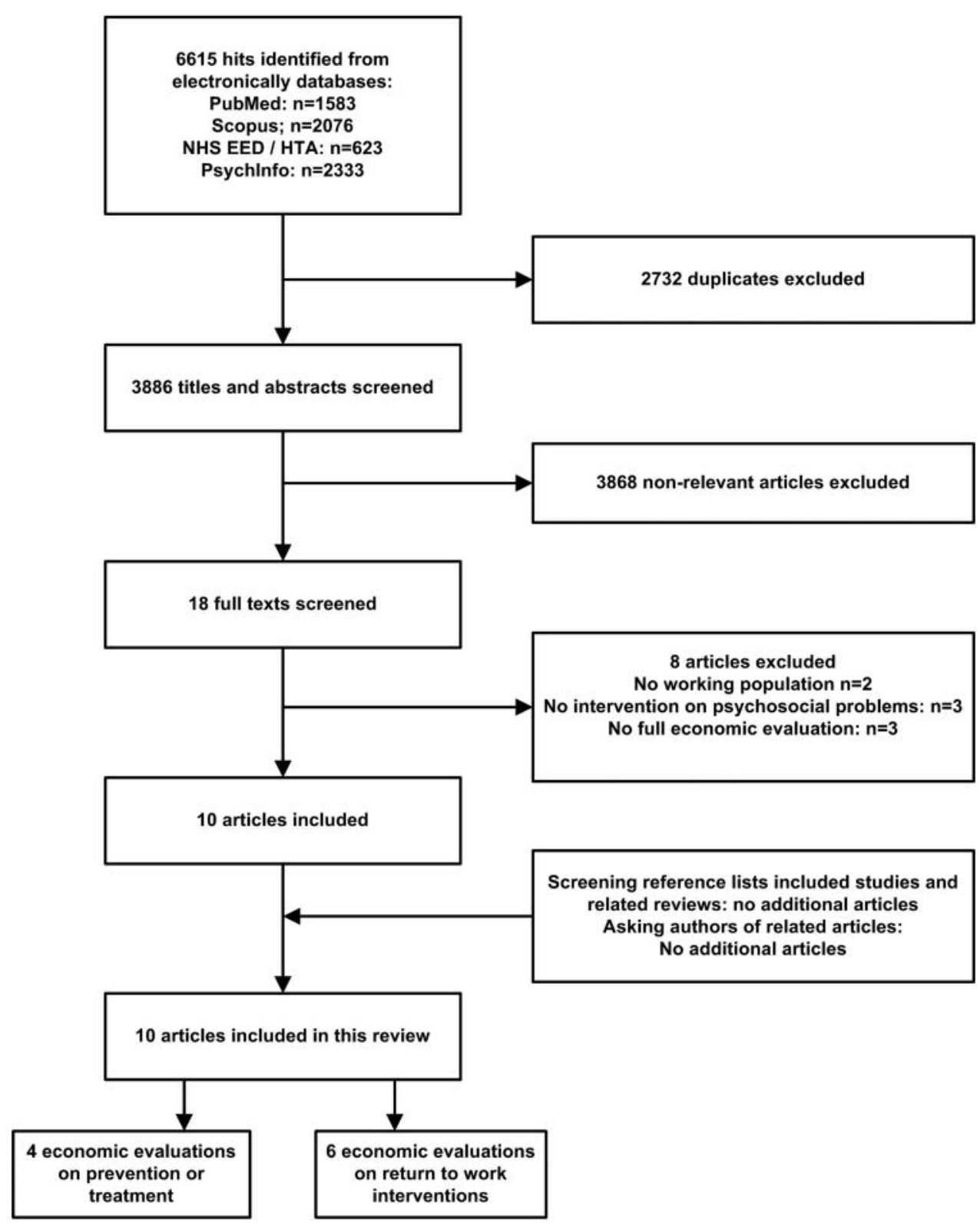

Figure 1 Flow chart: Inclusion of studies. 
Table 2 General characteristics of the included economic evaluation studies on mental health interventions aimed at prevention, treatment, or return to work among (sick-listed) workers

\begin{tabular}{|c|c|c|c|c|c|c|c|c|}
\hline Study & Population (N analyses) & $\begin{array}{l}\text { Intervention and control } \\
\text { condition }\end{array}$ & Design & Perspective & $\begin{array}{l}\text { Intervention period/ } \\
\text { time horizon }\end{array}$ & Effectiveness/benefits & Costs & $\begin{array}{l}\text { Sensitivity or } \\
\text { uncertainty } \\
\text { analysis }\end{array}$ \\
\hline \multicolumn{9}{|c|}{ Economic evaluation studies on mental health interventions aimed at prevention or treatment } \\
\hline $\begin{array}{l}\text { Lo Sasso } \\
\text { et } a^{25} ; \text { USA }\end{array}$ & $\begin{array}{l}\text { Employed primary care } \\
\text { patients with depression } \\
(\mathrm{n}=198)\end{array}$ & $\begin{array}{l}\text { Enhanced treatment }(N=96) \text {; } \\
\text { usual care }(N=102)\end{array}$ & $\begin{array}{l}\text { CBA alongside } \\
\text { RCT }\end{array}$ & Employer perspective & 2 years & $\begin{array}{l}\text { Productivity (absenteeism and } \\
\text { presenteeism) }\end{array}$ & $\begin{array}{l}\text { Intervention costs; healthcare } \\
\text { costs (2000 US\$) }\end{array}$ & $\begin{array}{l}\text { Univariate and } \\
\text { multivariate } \\
\text { sensitivity } \\
\text { analyses }\end{array}$ \\
\hline $\begin{array}{l}\text { Bittman } \\
\text { et } a^{26} ; \text { USA }\end{array}$ & $\begin{array}{l}\text { Long-term care workers } \\
(\mathrm{n}=112)\end{array}$ & $\begin{array}{l}\text { Recreational music making: } \\
\text { intervention weeks 1-6 }(\mathrm{N}=43) \text {; } \\
\text { intervention weeks } 7-12(\mathrm{~N}=41)\end{array}$ & $\begin{array}{l}\text { CBA alongside } \\
\text { randomised } \\
\text { cross-over study }\end{array}$ & Not stated & $\begin{array}{l}\text { Intervention period: } \\
6 \text { weeks; follow-up: } \\
12 \text { weeks }\end{array}$ & $\begin{array}{l}\text { Mental health: burnout and mood } \\
\text { dimensions; satisfaction; turnover } \\
\text { rates }\end{array}$ & $\begin{array}{l}\text { Intervention costs; turnover } \\
\text { costs (US\$; year } \leq 2003 \\
\text { (not stated)) }\end{array}$ & $\begin{array}{l}\text { No sensitivity } \\
\text { analyses }\end{array}$ \\
\hline $\begin{array}{l}\text { Wang et } a l^{6} \text {; } \\
\text { USA }\end{array}$ & $\begin{array}{l}\text { Hypothetical cohort of } \\
40 \text {-year-old workers (N not } \\
\text { stated) }\end{array}$ & $\begin{array}{l}\text { Screening and enhanced } \\
\text { depression care; usual care }\end{array}$ & $\begin{array}{l}\text { CUA and CBA } \\
\text { (Markov model) }\end{array}$ & $\begin{array}{l}\text { Societal perspective (CUA) } \\
\text { and employer-purchaser } \\
\text { perspective (CBA) }\end{array}$ & $\begin{array}{l}\text { Intervention period: } \\
18 \text { months; CUA: } \\
\text { lifetime; CBA: } 5 \\
\text { years }\end{array}$ & $\begin{array}{l}\text { CUA: quality of life from (discounted } \\
\text { at } 3 \% \text { ); CBA: productivity; turnover } \\
\text { and psychiatric hospitalisation }\end{array}$ & $\begin{array}{l}\text { CUA: intervention costs; } \\
\text { healthcare costs (discounted } \\
\text { at 3\%); CBA: intervention } \\
\text { costs; healthcare costs } \\
\text { (2004 US\$) }\end{array}$ & $\begin{array}{l}\text { Univariate and } \\
\text { probabilistic } \\
\text { sensitivity } \\
\text { analyses }\end{array}$ \\
\hline $\begin{array}{l}\text { Vogt et a }\left.\right|^{27} \text {; } \\
\text { Denmark }\end{array}$ & $\begin{array}{l}\text { Air traffic controllers (ATCOs) } \\
\text { who experienced a (critical) } \\
\text { incident }(N=38 \text { ) from the } \\
\text { German Air Traffic Control } \\
\text { Services }\end{array}$ & $\begin{array}{l}\text { CISM Programme: }(\mathrm{N}=18) \\
\text { compared with no intervention } \\
(\mathrm{N}=20)\end{array}$ & $\begin{array}{l}\text { CBA alongside } \\
\text { cohort study } \\
\text { (not stated) }\end{array}$ & Not stated & 5 years & $\begin{array}{l}\text { RTW (short term): time between } \\
\text { critical incident and full recovery; work } \\
\text { performance; self-reported contribution } \\
\text { of the CISM-programme on recovery }\end{array}$ & $\begin{array}{l}\text { Intervention costs } \\
\text { (2003 US\$) }\end{array}$ & $\begin{array}{l}\text { No sensitivity } \\
\text { analyses }\end{array}$ \\
\hline \multicolumn{9}{|c|}{ Economic evaluations on interventions aimed at RTW among sick-listed workers } \\
\hline $\begin{array}{l}\text { Van Oostrom } \\
\text { et } a^{28} \text {; The } \\
\text { Netherlands }\end{array}$ & $\begin{array}{l}\text { Employees with distress, } \\
2-8 \text { weeks on sick leave } \\
\text { ( } N=145 \text { ) }\end{array}$ & $\begin{array}{l}\text { Participatory RTW-intervention at } \\
\text { occupational health services } \\
\text { (N=73); usual care }(N=72)\end{array}$ & $\begin{array}{l}\text { CEA, CUA and } \\
\text { CBA alongside } \\
\text { RCT }\end{array}$ & $\begin{array}{l}\text { Societal perspective } \\
\text { (CUA and CEA); employer } \\
\text { perspective (CBA) }\end{array}$ & 12 months & RTW; QALYS & $\begin{array}{l}\text { Intervention costs; healthcare } \\
\text { costs; costs of occupational } \\
\text { health services; productivity } \\
\text { costs }(2008 €)\end{array}$ & $\begin{array}{l}\text { Univariate } \\
\text { sensitivity } \\
\text { analysis; } \\
\text { uncertainty } \\
\text { analyses }\end{array}$ \\
\hline $\begin{array}{l}\text { Brouwers } \\
\text { et } a l^{29} ; \text { The } \\
\text { Netherlands }\end{array}$ & $\begin{array}{l}\text { Patients with minor mental } \\
\text { health problems on sick leave } \\
\text { (max } 3 \text { months) ( } N=194 \text { ) }\end{array}$ & $\begin{array}{l}\text { Intervention by trained social } \\
\text { workers on problem-solving } \\
\text { strategies }(N=98) \text {; routine GP } \\
\text { care }(N=96)\end{array}$ & $\begin{array}{l}\text { CEA, CUA and } \\
\text { CBA alongside } \\
\text { RCT }\end{array}$ & Not stated & $\begin{array}{l}\text { Intervention period: } \\
10 \text { weeks; follow-up: } \\
18 \text { months; }\end{array}$ & $\begin{array}{l}\text { Sick leave duration; functional status; } \\
\text { health status; medical consumption }\end{array}$ & $\begin{array}{l}\text { Intervention costs; direct } \\
\text { healthcare costs; indirect } \\
\text { costs of production losses } \\
(€ ; \text { year } \leq 2010 \text { (not stated)) }\end{array}$ & $\begin{array}{l}\text { Univariate } \\
\text { sensitivity } \\
\text { analyses; } \\
\text { uncertainty } \\
\text { analysis }\end{array}$ \\
\hline $\begin{array}{l}\text { Leon et a } a^{30} \text {; } \\
\text { USA }\end{array}$ & $\begin{array}{l}\text { Employees with long-term } \\
\text { disability claims for } \\
\text { depression }(\mathrm{N}=598)\end{array}$ & $\begin{array}{l}\text { Depression-screening programme, } \\
\text { antidepressant medication and } \\
\text { sessions with a psychiatrist }\end{array}$ & $\begin{array}{l}\text { CBA based on a } \\
\text { simulation study }\end{array}$ & Not stated & 1 year & $\begin{array}{l}\text { RTW; savings for the insurance } \\
\text { company }\end{array}$ & $\begin{array}{l}\text { Treatment costs (US\$; year } \\
\leq 2002 \text { (not stated)) }\end{array}$ & $\begin{array}{l}\text { Univariate } \\
\text { sensitivity } \\
\text { analyses }\end{array}$ \\
\hline $\begin{array}{l}\text { Rebergen } \\
\text { et } a^{31} \text {; The } \\
\text { Netherlands }\end{array}$ & $\begin{array}{l}\text { Police workers on sick leave } \\
\text { due to mental health problems } \\
(\mathrm{N}=240)\end{array}$ & $\begin{array}{l}\text { Activating } \mathrm{GBC} \text { by trained } \\
\text { occupational physicians }(\mathrm{N}=125) \text {; } \\
\text { usual care }(\mathrm{N}=115)\end{array}$ & $\begin{array}{l}\text { CEA and CBA } \\
\text { alongside RCT }\end{array}$ & $\begin{array}{l}\text { CEA: societal perspective; } \\
\text { CBA: employer perspective }\end{array}$ & 1 year follow-up & Sick leave duration & $\begin{array}{l}\text { Healthcare costs; } \\
\text { productivity costs }(2003 €)\end{array}$ & $\begin{array}{l}\text { Univariate } \\
\text { sensitivity } \\
\text { analyses } \\
\text { uncertainty } \\
\text { analyses }\end{array}$ \\
\hline $\begin{array}{l}\text { Schene } \\
\text { et } a^{32} \text {; The } \\
\text { Netherlands }\end{array}$ & $\begin{array}{l}\text { Adults with major depression } \\
\text { and mean absenteeism of } \\
242 \text { days }(N=62)\end{array}$ & $\begin{array}{l}\text { Addition of occupational therapy } \\
\text { to treatment as usual }(\mathrm{N}=30) \text {; } \\
\text { treatment as usual }(\mathrm{N}=32)\end{array}$ & $\begin{array}{l}\text { CEA, CBA } \\
\text { alongside RCT } \\
\text { (not stated) }\end{array}$ & Not stated & $\begin{array}{l}\text { Intervention period: } \\
48 \text { weeks; time } \\
\text { horizon: } 12 \text { months }\end{array}$ & $\begin{array}{l}\text { Depression; work resumption; work } \\
\text { stress; productivity }\end{array}$ & $\begin{array}{l}\text { Healthcare costs (US\$; year } \\
\leq 2007 \text { (not stated)) }\end{array}$ & $\begin{array}{l}\text { Univariate } \\
\text { sensitivity } \\
\text { analyses (not } \\
\text { stated) }\end{array}$ \\
\hline $\begin{array}{l}\text { Uegaki } \\
\text { et } a^{33} \text {; The } \\
\text { Netherlands }\end{array}$ & $\begin{array}{l}\text { Workers with stress-related } \\
\text { sick leave for no longer than } \\
3 \text { months }\end{array}$ & $\begin{array}{l}\text { Minimal intervention (MISS) by } \\
\mathrm{GPs}(\mathrm{N}=227) \text {; usual care } \\
(\mathrm{N}=206)\end{array}$ & $\begin{array}{l}\text { CUA alongside } \\
\text { cluster RCT }\end{array}$ & Societal perspective & $\begin{array}{l}\text { Intervention period: } \\
4 \text { weeks; time } \\
\text { horizon: } 12 \text { months }\end{array}$ & QALYS & $\begin{array}{l}\text { Intervention costs; healthcare } \\
\text { costs productivity costs; } \\
\text { patient/family costs (2004 €) }\end{array}$ & $\begin{array}{l}\text { Univariate } \\
\text { sensitivity } \\
\text { analyses; } \\
\text { uncertainty } \\
\text { analyses }\end{array}$ \\
\hline
\end{tabular}




\section{Return to work}

The six economic evaluations on RTW interventions were in the occupational health service setting, ${ }^{28} 3132$ in a GP setting, ${ }^{33} 29$ or conducted by a psychiatrist. ${ }^{30}$ One study focused on sick-listed employees from an insurance company, ${ }^{30}$ one study was aimed at sick-listed police officers, ${ }^{31}$ and four studies contained mixed groups of absent workers. The study of Leon et $a l^{30}$ was carried out in the USA, the remaining five economic evaluations on RTW interventions were from The Netherlands. If stated in the article, the cost-benefit analyses were performed from the employers' perspective, whereas the $\mathrm{CE}$ and cost-utility analyses were done from the societal perspective. In the latter, costs included healthcare costs (including intervention costs), and effectiveness was related to psychosocial functioning or OALY. For the cost-benefit analyses that were done from the employers' perspective, intervention costs were compared with the reduced costs due to productivity loss. Thus, healthcare costs were not included. All included economic evaluations on RTW carried out a sensitivity or uncertainty analysis.

\section{Quality of the studies}

Table 1 shows the quality of each study represented by the scoring of the CHEC list criteria. On average, $65 \%$ of the criteria were met, that is $45 \%$ for the economic evaluations on prevention or treatment, ${ }^{25} 27$ and $71 \%$ for the economic evaluations on RTW interventions. ${ }^{28} 3031$

Four studies were classified as high quality, three as moderate and three as low quality. Two of the four economic evaluations on prevention or treatment were classified as low quality, one as moderate quality and one as high quality. For the economic evaluations on RTW interventions, three of six were classified as high quality, two as moderate and one as low quality.

Thirteen out of 19 items were fulfilled by more than $50 \%$ of the articles. For the articles on prevention or treatment and RTW interventions, these are four and 14 items, respectively. The items that were fulfilled by more than $50 \%$ of the articles were in the field of an appropriate study design, time horizon, identification of relevant outcome measures and the absence of conflicting interests. The items that were fulfilled by $50 \%$ or less of the articles were the chosen perspective, the valuation of costs, measurement of outcomes, discussion on generalisability and an ethical discussion.

\section{Results on the economic impact of the studies}

Table 3 presents the results of the economic evaluation studies on the prevention or treatment of mental health problems, or RTW interventions among workers sick-listed due to mental health problems.

\section{Prevention and treatment}

All four economic evaluations on the prevention or treatment of mental health problems found a potentially favourable financial return, but results of three of these studies were uncertain, due to low to moderate quality. ${ }^{26} 2736$ The high-quality study of Lo Sasso et al, ${ }^{25}$ however, consistently showed a favourable financial return of enhanced care for depressed workers compared with usual care. They found that the benefits due to enhanced treatment exceeded the costs, compared with usual care, even from the most conservative assumptions in a sensitivity analysis. Benefits from increased work productivity after 1 and 2 years yield $\$ 2100$ and $\$ 5500$ per participating employee, respectively. Intervention and healthcare costs after
1 and 2 years accounted for $\$ 735$ and $\$ 353$ per participating employee, respectively. This resulted in a net benefit, after 1 year, of US\$30 per worker with an increase to US\$257 per worker after 2 years. The ROI was $302 \%$ over the course of 2 years, that is, for every dollar invested, the gain for the employer is $302 \%$ (a return of US\$ 4.02). Results of different univariate and multivariate sensitivity analyses showed that the net benefit after 2 years ranged from US\$101 to US\$494 per worker, and ROI ranged from $20 \%$ to $566 \%$.

Wang et $a l^{6}$ evaluated the economic impact of enhanced depression care after depression screening. From the societal perspective, the ICUR was US\$20 000 per OALY gained $(95 \%$ CI US\$9200 to US\$49000) over the course of 5 years. The employers' perspective showed that benefits from increased productivity, reduced turnover and lower psychiatric hospitalisation (ie, US\$29.8 per employee) may exceed investments cumulative over 5 years (US\$26.9 per employee). This means a net benefit of US\$29 per worker.

Investing in recreational music-making for long-term care workers, or investing in CISM for air traffic controllers after having experienced a critical accident may lead to savings from increased work productivity. ${ }^{26} 27$ Bittman et $a l^{26}$ and Vogt et $a l^{27}$ reported on savings per worker (for every dollar invested) of $\$ 61$ annually, and $\$ 257$ after 5 years, respectively. However, the effectiveness of these interventions is uncertain, because no control group was included in the analyses, and robustness of the results was not tested in a sensitivity analyses.

\section{Return to work}

In five out of six economic evaluation studies on RTW interventions no evidence was found for a favourable CE or costbenefit balance of RTW interventions. The study of Schene et $\mathrm{al}^{32}$ however, reported on a likelihood of being $76 \%$ costeffective. This study of moderate methodological quality analysed the economic impact of occupational therapy as an additional treatment to usual care among sick-listed adults with major depression compared with care as usual alone. The number of days until work resumption was statistically significantly smaller for the intervention group compared with the control group: 207 days vs 299 days. The net benefit per person calculated, was US\$15 and US\$11 for the intervention group compared with the control group.

Three economic evaluations, of which two of high quality and one of moderate quality, found no statically significant differences between the intervention and control group in RTW rates, OALYs and costs of productivity loss. ${ }^{28} 2933$ The intervention costs were thus not compensated by the benefits from these outcome measures.

The high-quality study of Rebergen et al ${ }^{31}$ found statistically significant lower health utilisation costs (including intervention costs) for guideline-based care by occupational physicians for sick-listed police workers compared with usual care. Health utilisation costs were $€ 2100$ (SD €2000) in the intervention group, and $€ 2700$ (SD $€ 1600$ ) in the control group with a mean difference of $€ 520$ ( $95 \%$ CI $€ 980$ to $€ 17$ ). However, no statistically significant differences in costs due to productivity loss were found. Based on an acceptability curve, the probability of being cost-effective did not exceed $50 \%$. Net benefits were $€ 3600$, but these results were not robust.

A simulation study on a depression-screening programme followed by treatment for employees with long-term disability claims found net benefits ranging from US\$-444000 to US\$3 900000 compared with usual care, which was not robust. This simulation study was of low quality. There was a large 
Table 3 Study outcome of the included economic evaluations on mental health interventions that were focused on prevention, treatment or return-to-work for (sick-listed) workers

\begin{tabular}{|c|c|c|c|c|}
\hline Study & Effectiveness/benefits & Costs & $\begin{array}{l}\text { ICER/ICUR/CBR/net costs or } \\
\text { benefits/ROI }\end{array}$ & $\begin{array}{l}\text { Sensitivity or uncertainty } \\
\text { analysis }\end{array}$ \\
\hline \multicolumn{5}{|c|}{ Economic evaluation studies on mental health interventions aimed at prevention or treatment } \\
\hline $\begin{array}{l}\text { Lo Sasso } \\
\text { et } a l^{25} ; \text { USA }\end{array}$ & $\begin{array}{l}\text { Incremental benefits year } 1 \text { : US } \$ 2100 \\
\text { per participating employee; year } 2 \text { : US } \\
\$ 5500\end{array}$ & $\begin{array}{l}\text { Incremental costs year 1: US } \\
\$ 735 \text { per participating } \\
\text { employee; year } 2 \text { : US\$353 }\end{array}$ & $\begin{array}{l}\text { Net benefits year 1: US } \$ 30 \text { per worker; } \\
\text { year 2: US } \$ 257 \text { per worker; ROI over } \\
2 \text { years: } 302 \%\end{array}$ & $\begin{array}{l}\text { Net benefits year } 1 \text { ranges between } \\
\text { US\$-69 and } 130 \text { per worker; year 2: } \\
\text { between US\$101 and US\$494 per } \\
\text { worker; ROI over } 2 \text { years: } 20-566 \%\end{array}$ \\
\hline $\begin{array}{l}\text { Bittman } \\
\text { et }\left.a\right|^{26} ; \text { USA }\end{array}$ & $\begin{array}{l}46 \% \text { improvement burnout and mood } \\
\text { dimensions; reduction in turnover of } \\
18 \%\end{array}$ & $\begin{array}{l}\text { Intervention costs: US } \$ 1500 \text { per } \\
\text { year; average costs per } \\
\text { turnover: US } \$ 8100\end{array}$ & $\begin{array}{l}\text { Average cost savings of US } \$ 89100 \text { for a } \\
\text { single typical } 100 \text {-bed facility; 'ROI': US } \\
\$ 60 \text { saved for every dollar invested }\end{array}$ & No sensitivity analyses \\
\hline $\begin{array}{l}\text { Wang et } a l^{6} \text {; } \\
\text { USA }\end{array}$ & $\begin{array}{l}\text { CUA: incremental effectiveness: } 0.02 \\
\text { QALYS (intervention 18.8 QALYs per } \\
\text { person; usual care: } 18.7 \text { OALYs per } \\
\text { person); CBA: savings of US } \$ 29800 \\
\text { per } 1000 \text { employees }\end{array}$ & $\begin{array}{l}\text { CUA: incremental costs: US } \\
\$ 39.9 \text { per person (intervention } \\
\text { US } \$ 3700 \text {; usual care US } \$ 3600 \text { ); } \\
\text { CBA: costs of US } \$ 26900 \text { per } \\
1000 \text { employees }\end{array}$ & $\begin{array}{l}\text { CUA: ICER US } \$ 20000 \text { per OALY gained; } \\
\text { CBA: net benefits of US } \$ 2900 \text { per } 1000 \\
\text { workers }\end{array}$ & $\begin{array}{l}\text { CUA: univariate sensitivity analyses: } \\
\text { ICER most sensitive to treatment } \\
\text { costs; probabilistic sensitivity } \\
\text { analyses: } 95 \% \text { Cl: US } \$ 9200 \text { to US } \\
\$ 49000 ; \text { CBA: results most sensitive } \\
\text { to treatment costs }\end{array}$ \\
\hline $\begin{array}{l}\text { Vogt et } a l^{27} \\
\text { Denmark }\end{array}$ & $\begin{array}{l}\text { Mean RTW intervention and control } \\
\text { group: } 4 \text { and } 1 \text { day. } 32 \text { workers } \\
\text { recovered } 1 \text { day faster and } 5 \text { recovered } \\
3 \text { days faster: total } 47 \text { days. Total } \\
\text { savings from increased work recovery: } \\
47 \times \text { US } \$ 958 \text { (mean daily wage)=US } \\
\$ 45026\end{array}$ & $\begin{array}{l}\text { Intervention costs: US } \$ 268 \text { per } \\
\text { worker. For } 47 \text { workers (=N at } \\
\text { baseline): US } \$ 12596\end{array}$ & $\begin{array}{l}\text { Cost reduction per } 47 \text { workers: US } \\
\$ 45026-U S \$ 12596=\text { US } \$ 32430 \text {; ROI: } \\
257 \%\end{array}$ & No sensitivity analyses \\
\hline \multicolumn{5}{|c|}{ Economic evaluations on interventions aimed at RTW among sick-listed workers } \\
\hline $\begin{array}{l}\text { Van Oostrom } \\
\text { et } a l^{28} ; \text { The } \\
\text { Netherlands }\end{array}$ & $\begin{array}{l}\text { No statistically significant differences } \\
\text { between groups in QALYs and RTW } \\
\text { subgroup of employees with intention } \\
\text { to RTW: } 62 \text { days sick leave gain }\end{array}$ & $\begin{array}{l}\text { No statistically significant } \\
\text { differences between groups }\end{array}$ & $\begin{array}{l}\text { ICER: } € 627 \text { per 1-day reduction in sick } \\
\text { leave; ICUR: } € 1846001 \text { per OALY; CBA: } \\
\text { net costs of } € 2000 \text {; subgroup analysis: } \\
\text { ICER: €10; ICUR: €124000; CBA: } € 6200\end{array}$ & $\begin{array}{l}\text { Uncertainty analysis: ICER and ICUR } \\
\text { not robust }\end{array}$ \\
\hline $\begin{array}{l}\text { Brouwers } \\
\text { et } a l^{29} ; \text { The } \\
\text { Netherlands }\end{array}$ & $\begin{array}{l}\text { No statistically significant difference } \\
\text { between the groups on functional } \\
\text { status, health status and sick leave } \\
\text { duration }\end{array}$ & $\begin{array}{l}\text { No statistically significant } \\
\text { differences between groups }\end{array}$ & $\begin{array}{l}\text { ICER: } € 167 \text { and } € 81 \text { per improvement } \\
\text { health score; ICUR: } € 4200 \text { per QALY } \\
\text { gained; CBA: net costs: } € 11(95 \% \mathrm{Cl} \\
-1800 \text { to } 1800)\end{array}$ & $\begin{array}{l}\text { Univariate sensitivity analyses: } \\
\text { results robust; uncertainty analyses: } \\
\text { ICER not significant }\end{array}$ \\
\hline $\begin{array}{l}\text { Leon et } a l^{30} \\
\text { USA }\end{array}$ & $\begin{array}{l}\text { 5-52 non-cancer claimants RTW: } \\
\text { savings of US } \$ 500000-U S \$ 5200000 \text {; } \\
2-22 \text { cancer claimants RTW: savings } \\
\text { of US } \$ 200000-U S \$ 2200000\end{array}$ & $\begin{array}{l}\text { Total costs between US } \$ 520000 \\
\text { and US } \$ 1300000 \text { for non-cancer } \\
\text { claimants and between US } \\
\$ 418000 \text { and US } \$ 1044000 \text { for } \\
\text { cancer claimants }\end{array}$ & $\begin{array}{l}\text { Net benefits between US\$- } 21300 \text { and } \\
\text { US } \$ 3897000 \text { for non-cancer claimants } \\
\text { and between US\$- } 444400 \text { and US } \\
\$ 1156000 \text { for cancer claimants; costs } \\
\text { offset if } 5-40 \% \text { of non-cancer claimants } \\
\text { would RTW or } 9-75 \% \text { of cancer } \\
\text { claimants would RTW }\end{array}$ & $\begin{array}{l}\text { Large ranges in estimations for } \\
\text { different assumptions }\end{array}$ \\
\hline $\begin{array}{l}\text { Rebergen } \\
\text { et } a l^{31} ; \text { The } \\
\text { Netherlands }\end{array}$ & $\begin{array}{l}\text { No significant differences in days of } \\
\text { sick leave and costs of loss of } \\
\text { productivity; health utilisation costs: } \\
€ 2100 \text { (SD } € 2000 \text { ) in the intervention } \\
\text { group and } € 2700 \text { (SD } € 1600 \text { ) in the } \\
\text { control group; mean difference of } € 520 \\
(95 \% \text { Cl } € 980 \text { to } € 17)\end{array}$ & $\begin{array}{l}\text { Intervention costs: intervention } \\
\text { group: } € 552 \text { (SD 280); control } \\
\text { group: } € 486 \text { (SD 277); } \\
\text { difference } € 66(€ 2-151)\end{array}$ & $\begin{array}{l}\text { CEA: } € 736 / \text { day on sick leave; } \\
\text { acceptability curve did not exceed the } \\
\text { probability of being cost-effective of } \\
50 \% \text {; CBA: net benefit } s \text { of } € 3600\end{array}$ & $\begin{array}{l}\text { Univariate sensitivity analyses: } \\
\text { overall results remain similar } \\
\text { (robust); uncertainty analyses: not } \\
\text { robust }\end{array}$ \\
\hline $\begin{array}{l}\text { Schene } \\
\text { et } a l^{32} ; \text { The } \\
\text { Netherlands }\end{array}$ & $\begin{array}{l}\text { No statistically significant differences } \\
\text { between groups in percentage of } \\
\text { patients with major depression and } \\
\text { work stress; mean number of days } \\
\text { until work resumption intervention } \\
\text { group: } 207 \text { days; control group: } \\
299 \text { days; } \mathrm{RR}=2.71 \text { ( } 95 \% \mathrm{Cl} 1.16 \text { to } \\
6.29 \text { ) }\end{array}$ & $\begin{array}{l}\text { No statistically significant } \\
\text { differences between groups in } \\
\text { total healthcare costs }\end{array}$ & $\begin{array}{l}\text { Net benefits per person intervention } \\
\text { group: US } \$ 15 \text {; control group: US } \$ 11 \text {; } \\
\text { likelihood of being cost-effective is } 76 \%\end{array}$ & $\begin{array}{l}\text { Univariate sensitivity analyses; } \\
\text { results are robust }\end{array}$ \\
\hline $\begin{array}{l}\text { Uegaki } \\
\text { et } a^{33} ; \text { The } \\
\text { Netherlands }\end{array}$ & $\begin{array}{l}\text { No statistically significant differences } \\
\text { in OALYs between groups }\end{array}$ & $\begin{array}{l}\text { No statistically significant } \\
\text { differences in healthcare costs } \\
\text { and productivity costs }\end{array}$ & $\begin{array}{l}\text { ICER: } € 7400 \text {; for willingness-to-pay } \\
\text { thresholds from } € 0 \text { to } € 100000 \text {, the } \\
\text { probability of being cost-effective is } \\
0.58-0.90\end{array}$ & $\begin{array}{l}\text { Univariate sensitivity analyses: } \\
\text { ICERs ranged between } € 37900 \text { and } \\
€ 46100 \text { (not robust) }\end{array}$ \\
\hline \multicolumn{5}{|c|}{ 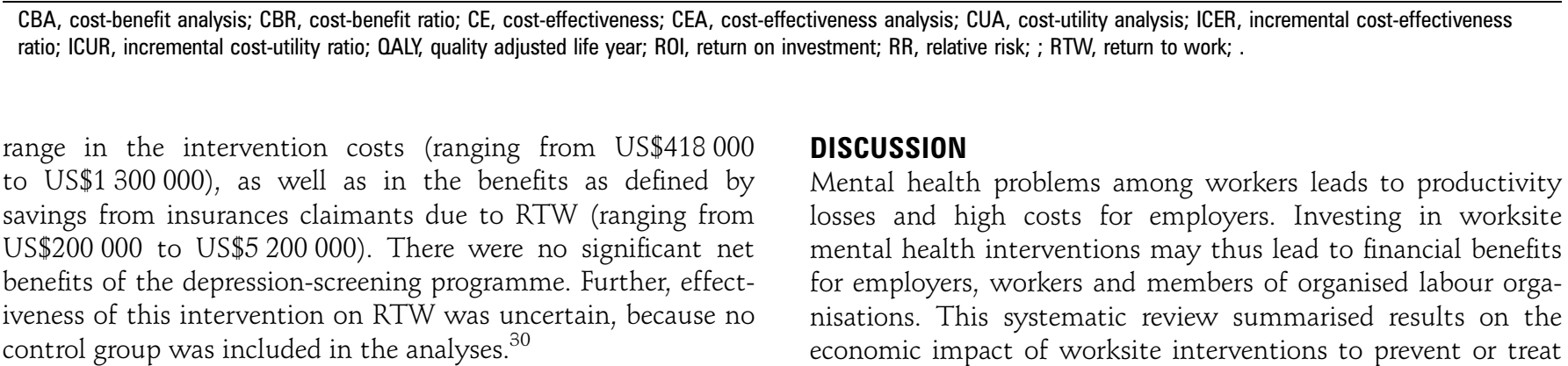 } \\
\hline
\end{tabular}


mental health problems, or to improve RTW of sick-listed workers. Only 10 economic evaluations on worksite mental health interventions were found, of which the majority was of low methodological quality, or evidence on effectiveness was lacking. Therefore, no firm conclusions can be drawn from the results of this systematic review. Nonetheless, based on the results of the few existing studies including a full economic evaluation, worksite interventions to prevent or treat mental health problems seem to be cost-effective, while RTW interventions aimed at depressed employees do not seem to be cost beneficial.

\section{Quality of the economic evaluations}

In this systematic review, three studies were considered as low methodological quality, and four studies were classified as moderate quality. Due to the associated risk of bias, the results of those studies should be interpreted with caution. With regard to the different CHEC criteria, there were some quality items that were poorly met by the studies included. None of the studies on prevention or treatment (adequately) reported on the measurements of costs in physical units; for RTW interventions, $40 \%$ scored positively on this item. Moreover, only $25 \%$ and $40 \%$, respectively, had the costs valued appropriately, or did not report on this. As to the measurement and valuation of outcomes, about $50 \%$ met this criterion. Because the way of measurement and valuation of both costs and outcomes is essential in order to understand and interpret the results of an economic evaluation, there is a strong recommendation for future researchers to adequately measure and value costs and outcomes. Future economic evaluations should pay further attention to the description of the study population, the competing alternatives, and also the generalisability of the results and ethical issues. These items were also poorly reported in the studies under review.

\section{Evidence for effectiveness}

Half the included studies on the economic impact of RTW interventions were classified as high quality, the other half was of low to moderate quality. However, the studies with high quality did not prove that investment in worksite mental health programmes among sick-listed workers was either costeffective or yielded monetary benefits. This was probably due to lack of evidence on effectiveness of the RTW interventions included in the economic evalutions. ${ }^{28} 2933$ This raises the question about the value of an economic evaluation in case of a lack of a proven intervention effect. Since the intervention costs, and even the total costs, including healthcare costs and productivity-related costs, did not differ between the study groups, the intervention will not be cost-effective. Reasons for lacking evidence may lie in the complexity of the study population, that is, workers with probable severe mental health problems, who have been sick-listed for a longer period. From previous studies, it is known that different factors predict RTW for people with mental health problems, including work-related and non-work-related factors. ${ }^{36-38}$ More insight is needed in effective elements of interventions, as well as different types of effects of worksite mental health programmes.

\section{Study limitations}

Although this review was performed in a systematic way using common and accepted criteria, there are some limitations that should be mentioned. First, because of heterogeneity in type of mental health interventions, study population and methodology of economic evaluations, no synthesis of the data was possible. This makes it difficult to compare results of different economic evaluations and give an overall conclusion on the results. Instead, we decided to extensively report on the studies, and have summarised the evidence qualitatively.

Further, in the evaluation of the methodological quality of the studies, we applied the CHEC list. Although this checklist has been used before in systematic reviews on the economic evaluation, ${ }^{34} 35$ there are some issues worth discussing. First, all criteria are counted with the same weightage, while not all criteria are independent. One can imagine that some items contribute to potential bias of results more obvious than other items. However, it is difficult to find reliable weightages for each of the items. Second, although the scoring was done by two sets of reviewers independently, the scoring is quite subjective. Moreover, the scoring is dichotomous. Third, the cut-off points to categorise studies into low, moderate and high quality were arbitrary, although these cut-off points have been used in previous systematic reviews of economic evaluations studies using the CHEC list. ${ }^{34}{ }^{35}$ However, because all studies are scored in the same way by the same reviewers, the CHEC scores and the categorising can be used appropriately to mutually compare the risk of bias of the different economic evaluations that are included in this review.

Finally, in spite of the systematic search strategy, including the search in diverse electronic databases, reference check and contact with authors, we cannot exclude the possibility of having missed some economic evaluations on mental health interventions. For example, due to limitations in the language of publication and date of publication, economic evaluations on this topic might have been missed. By our focus on economic evaluations, studies that have examined the effectiveness of worksite mental health interventions, but did not evaluate the economic impact of the intervention were excluded. Therefore, from the results of his systematic review, we cannot draw conclusions on the general effectiveness of workplace mental health interventions.

\section{CONCLUDING REMARKS}

Due to a limited number of included economic evaluations, of which the majority was of low methodological quality, or evidence on effectiveness was lacking, only a tentative conclusion can be drawn from the results of this systematic review. Worksite interventions to prevent or treat mental health problems might be cost-effective, while RTW interventions aimed at depressed employees do not seem to be cost beneficial on the basis of those studies that included a full economic evaluation. As mentioned before, these tentative conclusions have to be taken with caution. Therefore, more high-quality economic evaluations of effective worksite mental health interventions are needed to gain more insight into the financial benefits of worksite mental health interventions. Before analysing this economic impact, there should first be ample evidence for the effectiveness of worksite mental health interventions.

Contributors All authors contributed to the work undertaken to generate this paper and have seen and approved the final manuscript.

Competing interests None.

Provenance and peer review Not commissioned; externally peer reviewed.

\section{REFERENCES}

1. Lepine JP, Briley M. The increasing burden of depression. Neuropsychiatr Dis Treat 2011;7(Suppl 1):3-7.

2. Wang J, Smailes E, Sareen J, et al. The prevalence of mental disorders in the working population over the period of global economic crisis. Can J Psychiatry 2010;55:598-605. 
3. WHO. Investing in mental health. Geneva: World Health Organization, 2003.

4. De Graaf R, Ten Have M, Van Dorsselaer S. The Netherlands Mental Health Survey and Incidence Study-2 (NEMESIS-2): design and methods. Int J Methods Psychiatr Res 2010;9:125-41.

5. Lelliot P, Tulloch S, Boardman J, et al. Mental health and work. London: The Royal College of Psychiatrists for the cross-government Health, Work and Well-being programme, 2008.

6. Wang PS, Patrick A, Avorn J, et al. The costs and benefits of enhanced depression care to employers. Arch Gen Psychiatry 2006;63:1345-53.

7. WHO. The global burden of disease: 2004 update. Geneva: World Health Organization, 2008

8. WHO. Mental health policies and programmes in the workplace. Mental health policy and service guidance package. Geneva: World Health Organization, 2005.

9. Backhuys Roozenboom M, Gouw P, Hooftman W, et al. State of the art in occupational health 2007/2008. Quality of work, consequences, and regulations in the Netherlands. Hoofddorp: TNO Quality of life, 2009.

10. Statline. Eectronic database for statistical information about societal and economic topics presented in tables and figures. Statistics Netherlands. Available at: http:// statline.cbs.nl. Accessed November, 2011.

11. Henderson $\mathbf{M}$, Glozier N, Elliott $\mathrm{KH}$. Long term sickness absence. BMJ 2005;330:802-3.

12. Koopmans GT, Lamers LM. Comparing patients with depressive complaints and patients with chronic medical conditions on their functioning and medical consumption. J Ment Health Policy Econ 2001;4:91-100.

13. Cuijpers P, Muñoz RF, Clarke GN, et al. Psychoeducational treatment and prevention of depression: the "Coping with Depression" course thirty years later. Clin Psychol Rev 2009;29:449-58

14. Ruotsalainen J, Serra C, Marine A, et al. Systematic review of interventions for reducing occupational stress in health care workers. Scand J Work Environ Health 2008;34:169-78.

15. Richardson KM, Rothstein HR. Effects of occupational stress management intervention programs: a meta-analysis. J Occup Health Psychol 2008;13:69-93.

16. Van Oostrom SH, Driessen MT, De Vet HCW, et al. Workplace interventions for preventing work disability. Cochrane Database of Syst Rev 2009;(2):CD006955.

17. Dietrich S, Deckert S, Ceynowa M, et al. Depression in the workplace: a systematic review of evidence-based prevention strategies. Int Arch Occup Environ Health 2012;85:1-11.

18. Timbie JW, Horvitz-Lennon M, Frank RG, et al. A meta-analysis of labor supply effects of interventions for major depressive disorder. Psychiatr Serv 2006:57:212-18.

19. Van der Klink JJ, Blonk RW, Schene AH, et al. The benefits of interventions for work-related stress. Am J Public Health 2001;91:270-6.

20. Nieuwenhuijsen K, Bultmann U, Neumeyer-Gromen A, et al. Interventions to improve occupational health in depressed people. Cochrane Database Syst Rev 2008;(2):CD006237.

21. Bosmans JE, van Schaik DJ, de Bruijne MC, et al. Are psychological treatments for depression in primary care cost-effective? J Ment Health Policy Econ 2008;11:3-15
22. Zechmeister I, Kilian R, McDaid D. Is it worth investing in mental health promotion and prevention of mental illness? A systematic review of the evidence from economic evaluations. BMC Public Health 2008;8:20.

23. Drummond MF, Sculpher MJ, Porrance GW, et al. Methods for the economic evaluation of health care programmes. 3rd edn. Oxford: Oxford University Press, 2005.

24. Evers S, Goossens $\mathrm{M}$, De Vet $\mathrm{H}$, et al. Criteria list for assessment of methodological quality of economic evaluations: consensus on health economic criteria. Int J Technol Assess Health Care 2005;21:240-5.

25. Lo Sasso AT, Rost K, Beck A. Modeling the impact of enhanced depression treatment on workplace functioning and costs: a cost-benefit approach. Med Care 2006;44:352-8.

26. Bittman B, Bruhn KT, Stevens C, et al. Recreational music-making: a cost-effective group interdisciplinary strategy for reducing burnout and improving mood states in long-term care workers. Adv Mind Body Med 2003;19:4-15.

27. Vogt J, Köper B, Leonhardt J, et al. Economic evaluation of CISM-A pilot study. Int J Emerg Ment Health 2004;6:185-96.

28. Van Oostrom SH, Heymans MW, De Vet HC, et al. Economic evaluation of a workplace intervention for sick-listed employees with distress. Occup Environ Med 2010;67:603-10.

29. Brouwers EP, De Bruijne MC, Terluin B, et al. Cost-effectiveness of an activating intervention by social workers for patients with minor mental disorders on sick leave: a randomized controlled trial. Eur J Public Health 2007:17:214-20.

30. Leon AC, Walkup JT, Portera L. Assessment and treatment of depression in disability claimants: a cost-benefit simulation study. J Nerv Ment Dis 2002;190:3-9.

31. Rebergen DS, Bruinvels DJ, Van Tulder MW, et al. Cost-effectiveness of guideline-based care for workers with mental health problems. J Occup Environ Med 2009;51:313-22

32. Schene $\mathbf{A H}$, Koeter MW, Kikkert MJ, et al. Adjuvant occupational therapy for work-related major depression works: randomized trial including economic evaluation. Psychol Med 2007;37:351-62.

33. Uegaki K, Bakker I, De Bruijne $\mathrm{M}$, et al. Cost-effectiveness of a minimal intervention for stress-related sick leave in general practice: results of an economic evaluation alongside a pragmatic randomised control trial. J Affect Disord 2010;120:177-87

34. Van Dongen JM, Proper KI, Van Wier MF, et al. Systematic review on the financial return of worksite health promotion programmes aimed at improving nutrition and/or increasing physical activity. Obes Rev 2011;12:1031-49.

35. Uegaki K, De Bruijne MC, Lambeek L, et al. Economic evaluations of occupational health interventions from a corporate perspective-a systematic review of methodological quality. Scand J Work Environ Health 2010;36:273-88.

36. Wang PS, Simon G, Kessler RC. The economic burden of depression and the cost-effectiveness of treatment. Int J Methods Psychiatr Res 2003:12:22-33.

37. Henderson $\mathbf{M}$, Harvey S, Overland S, et al. Work and common psychiatric disorders. J $R$ Soc Med 2011;104:198-207.

38. Blank L, Peters J, Pickvance $S$, et al. A systematic review of the factors which predict return to work for people suffering episodes of poor mental health. J Occup Rehabil 2008;18:27-34. 